\title{
Italian Female Social Entrepreneurship and Management: An Explorative Study on Social Cooperatives
}

\author{
Francesca Picciaia ${ }^{1}$ \\ ${ }^{1}$ Department of Economics, University of Perugia, Italy \\ Correspondence: Francesca Picciaia, Department of Economics, University of Perugia, Italy.
}

Received: May 22, 2020

Accepted: June 2, 2020

Online Published: June 4, 2020

doi:10.5430/jms.v11n2p56

URL: https://doi.org/10.5430/jms.v11n2p56

\begin{abstract}
Purpose: The main aim of this paper is to individuate the elements that have influenced and/or are influencing the constitution and the activity of a sample of Italian female social cooperative, and the relationship between gender and social enterprise's internal organization.

Methodology/Approach: This is an exploratory study based on a survey of a purposive sample of Italian Social Cooperatives (SCs). The selected SCs are led by women, in order to focus on motivations, constraints and opportunities behind the foundation of the social enterprise and the relationship among female gender, activity and organization.

Originality/Value: Albeit with initial insights, the study can contribute, with a country-specific analysis, to the debate on the interconnections amidst institutional environment, cultural and social elements and the development of the female entrepreneurship, with a focus on third sector.

Practical Implications: Research findings could help to highlight opportunities and constraints related to the phenomenon on female social entrepreneurship.
\end{abstract}

Keywords: Italy, female social entrepreneurship, social cooperative, mixed-method research

\section{Introduction}

Entrepreneurial initiative is recognized as a central element of economic growth and job creation (Blanchflower, Oswald, 1998; Parker, 2009). In the case of women entrepreneurs, in addition to the role of economic development (Minniti et al, 2005; Brush et al, 2006), scholars are also agreed to recognize a fundamental contribution to increase gender equality and social stability (Luchsinger, 2015). But currently, the gap between male and female entrepreneurial initiatives is still very wide (EU Directorate-General for Internal Policies, 2015), highlighting in 2012 an average rate of female entrepreneurs in EU around $29 \%$, consistent with the rest of the world, where this relationship attests to one third (McClelland et al, 2005). In general, it can be stated that "business has always been gendered" (Gamber, 1998: 216), and the context has always played a central role in the development and growth of female entrepreneurial initiatives (Doe, 2017).

Eagly (1987) states that the prevalence of men in business fields is essentially linked to culture and social structure, which define socially acceptable behaviours for men and women, and not to a biological predisposition. In this sense, entrepreneurship "takes place and has effects on different societal levels simultaneously" (Davidsson, Wiklund, 2001: 81), and "individual orientations are enmeshed and molded by economic, legal, normative and societal environments, supporting the thesis of entrepreneurship embedded-ness in specific social-cultural contexts" (Jamali, 2009: 233). Studying entrepreneurial phenomena therefore introduced the necessity to consider the environment in which the phenomenon develops (Welter, 2010), and the analysis of institutional, social and cultural aspects (De Bruin et al, 2007), within the well-known institutional framework (North, 1990; Powell, May 1991; Meyer, Rowan, 1991; Scott, 2008).

According to North (1990), the institution represents "a guide to human interaction" and "the humanly devised constraints that shape human interaction" (p. 3). For Scott (2008), institutional forces can be divided in three categories: regulative, normative and cultural-cognitive, providing "stability and meaning to social life" (2008: 48). These elements are deeply intertwined and interdependent from each other (Scott, 2008), and the final effect is that 
institutions determine what is appropriate or not, and thus make other actions unacceptable (Di Maggio, Powell, 1991) within a specific social order.

Starting from these theoretical considerations, several studies, focused mainly to profit and commercial realities, began to empirically deepen the topic of gender entrepreneurship through the lens of this multi-level approach, pointing out the interconnections among macro elements (that is to say normative institutions, male stereotypes, government support, country's stage of development) and micro ones (such as values and expectations, beliefs, motivations, opportunity identifications) (Jamali, 2009; Elam, Terjesen, 2010; Klyver et al, 2013). In recent times has been increasing also the interest on the role of women in the third sector, as shown by numerous studies with different purposes and approaches (Themudo, 2009; Teasdale et al, 2011; Hechavarria et al, 2012; Humbert, 2012; Huysentruyt, 2014; Urbano Pulido et al, 2014; Nicolás, Rubio, 2016) and by some European attempts in order to map the phenomenon (EU Directorate-General for Internal Policies, 2015; WeStart, 2015), but there is already a dearth of researches especially in relation of female social entrepreneurship topics (Teasdale et al, 2011; Gawell, Sundin, 2014).

This paper has the aim to contribute to the abovementioned topic through a survey on Italian social cooperatives (SCs), the most common social enterprises in the country. Focusing on a specific juridical form of social enterprise allow us to overcome the discussion about the absence of a consistently accepted definition of social enterprise (Light, 2008; Defourny, Nyssens, 2010; Teasdale, 2010; Teasdale et al, 2011). As there can see below, Italian SCs have specific entrepreneurial and social characteristics, and belong to the field of social enterprise.

Particularly, purpose of this study is to individuate the elements that influence the constitution and the activity of the SC. As an exploratory study, the survey has been conducted with a purposeful sample of eight SCs (selected after an online research and a phone pre-interview) and led by women, and has been focused on motivations, constraints and opportunities behind the foundation of the social enterprise and the relationship among female gender, activity and organization. Italian SCs represent a fundamental model in the third sector, because they constituted the booster of European individuation of social entrepreneurship (Defourny, Nyssens, 2010), arose primarily to respond, within the cooperative movement, to needs not adequately covered by public sector (Borzaga, Santuari, 2001). The focus on a specific nation, furthermore, responds to calls for deepening entrepreneurial behaviours and choices within a specific context (Welter, 2011).

\section{Literature Review}

There is now a huge body of literature exploring and analysing the relation between women and entrepreneurship, with a complex and different range of issues, approaches, methodologies. The increasing attention is confirmed also for the creation of specific journals on the theme (for example, International Journal of Gender and Entrepreneurship) or the presentation of special issues on women's entrepreneurial themes in leading journals as Entrepreneurship Theory and Practice or International Small Business Journal. During years, studies underlined the presence of significant differences between men's and women's motivations, characteristics, creation and development of business initiatives. Women's entrepreneurial initiatives are likely to differently perform in comparison of men's (Fischer et al, 1993; Fasci, Valdez, 1998; Du Rietz, Henrekson, 2000; Robb, 2002; Watson, 2002, 2003; Robb, Watson, 2012) also in SMEs experiences (Rosa et al, 1996; Watson, Robinson, 2003). Other studies (Carter et al, 2003; Fossen, 2012) stated that women are likely to be more risk and debt adverse, but different seem to be also motivations behind the creation of an enterprise: while men want to grow their new ventures to achieve financial success, for women, financial success is just one of many reasons to achieve growth (Manolova et al, 2011). Women's motivations are, so that, related to reasons of self-fulfilment, autonomy and social values (Bruni et al, 2004). A substantial part of the gender gap in entrepreneurial activity could be also the less confidence of women in their entrepreneurial skills, their different social networks and their higher fear of failure than men (Minniti, Schade, 2011).

Recently, research on businesswomen has been moving to new directions, both in terms of approaches and in terms of new fields (e.g. Ahl, 2006; Brush et al, 2009; Marlow, 2014). Echoing Marlow (2014), among different fields on studies of women's entrepreneurship, social entrepreneurship is one of the most interesting area of analysis but, despite Haugh's (2005) call for more gender aware researches on these topics, to date few studies appear to be published (Teasdale et al, 2011; Gawell, Sundin, 2014). The situation of women in non-profit sector is analysed in terms of management, workforce, and, more generally, entrepreneurship initiatives. The results of various studies underpin, in the third sector, the persisting unequal opportunity for women, who are both underrepresented and underpaid in management (Gibelmann, 2000; Mesch, Rooney, 2008), although, in comparison with traditional commercial enterprises, females are relatively more prevalent in social entrepreneurial activity and male-female pay 
gap is smaller (Leete, 2000; Faulk et al, 2013; Preston, Sacks, 2010). However, this varies significantly across country context (Huysentruyt, 2014) and by industry (Faulk et al, 2012; McGinnis, 2011; Salamon, Sokolowski, 2006).

Particularly, studies on gender and third sector are more prevalent in the topics of disparity in leadership positions, wage gap and composition of non-profit workforce, especially in US and UK (Gibleman, 2000; Mesch, Rooney, 2008; Sampson, Moore, 2008, Teasdale et al, 2011). On the other side, several studies focused on women and their overrepresentation in non-profit sector as workforce. The reasons are related to different elements, such as the so-called "labour donation theory" (Preston, 1989). For this theory, since non-profit wages tend to be lower than in other sectors, this gap is considered a sort of donation, providing goods and services with social externalities. As underlined by Conry and McDonald (1994) and Lanfranchi and Narcy (2015), other possible explanations are linked to the nature of non-profit work, typically women-centred, and for intrinsic values and rewards and to the great offering of family-friendly benefits, part-time jobs and shorter workweeks.

Within the topic of social entrepreneurship and gender propensity and barriers, such as in the mainstream entrepreneurship studies, the literature converges to the existence of a divide between male and female approach, especially regarding personal characteristics and opportunity recognitions. Businessmen are more likely than female ones to exhibit economic value creation goals, whilst women's entrepreneurs are more likely than men to emphasize social and environmental value creation (Hechavarria et al, 2012; Nicolás, Rubio, 2016; Themudo, 2009). Other differences are related to female attitudes towards long term helping and altruistic behaviours (Eagly, Crowley, 1986; Eckel, Grossman, 1998; Levie, Hart, 2011; Huysentruyt 2014, Urbano Pulido et al, 2014), volunteer activities (DiMaggio, Louch, 1997), and finally aversion toward competition and the markets (Huysentruyt, 2014). There remains a paucity, instead, about other elements behind the setting up of a social enterprise by a woman (Humbert, 2012; Gras et al, 2014). However, it has to be noted that these results, both in terms of mainstream and of social entrepreneurship, "are statistical rather than absolute, and there is of course considerable overlap between the female and male distribution" (Teasdale at al, 2011: 69), since they risk to become myths and stereotypes themselves.

One thing that emerges from the literature on businesswomen in general is the necessity of understanding the context within which the phenomenon developed. As such, Doe (2017: 348) writes that "the aim of all business is surely gender neutral since all enterprises need to achieve a profit. But it is attitudes, aims and ambitions that shape a business and these can be affected by the circumstances of the owner and the environment, political or social, in which he or she lives". The analysis of the impact of contextual factors is, of course, central in the study of every entrepreneurial experience (Bowden, 2016). However, in the case of female-directed and female-owned businesses, this becomes essential, because of the additional constraints and restrictions that every woman experienced in her business.

To this sense, starting from institutional approach, there has been an increasing attention on studies with a multi-level research design, in which the phenomenon of female entrepreneurship is considered as a network of interconnected micro-, meso- and macro-elements (De Bruin et al, 2007; Brush et al, 2009; Jamali, 2009; Welter, 2011; Jennings, Brush, 2013). Macro-level involves what it can be defined structural conditions (social values, social stratifications, general conception of family, work and law, economic environment), micro-level is related to individual factors (motivations, opportunities, identity), and meso-level concerns organizational processes that mediate opportunities in relation to circumstances (Jamali, 2009). Moreover, and in specific relation to social enterprise, most of these elements are also picked up by a recent European project (Policy Department - Citizen's Rights and Constitutional Affairs, 2015) named “Women's entrepreneurship: closing the gender gap in access to financial and other services and in social entrepreneurship". In this document it is confirmed the less gender gap in comparison with mainstream enterprises, but emerges the central role played by national legal framework in the development of women's activities and the more complexity of access to finance due to the characteristics of social enterprises.

\section{The Italian Social Cooperatives}

The Italian social cooperative (SC) - introduced in the Italian legal system in 1991 - represents the first (successful) attempt to set up a normative framework for social enterprises (Defourny, Nyssens, 2008). This legal form is designed to connect entrepreneurial dynamics with social aims and points out a sort of inversion of the profit-making firm (Mancino, Thomas, 2005). Profit institution has the aim to achieve economic growth in condition of optimal profitability, and social elements (of workers, community, and environment) represent just ways to realize as better as possible the principal purpose. Instead for social cooperatives (and, generally, for all social enterprises) the main 
aim is to provide social goods "according to criteria of economic rationality and efficient use of available resources" (Thomas, 2004: 248).

Italian law, particularly, identifies two different kinds of SCs: the first one (A-type) is related to the provision of social and caring services (regulated by the law), such as social and health activities, and educational services. B-type social cooperative covers the integration of disadvantage people, who are unable to enter in the traditional job market, into the workforce. In order to become an A-type social cooperative, it is necessary to achieve the majority of the total revenues from areas determined by the law. Alternatively, the B-type one must have at least $30 \%$ of its employees in the "disadvantaged" category, but there is no limit in terms of area of activity.

\section{Research Methodology}

The research undertaken is based on a mixed method approach that encompasses both qualitative and quantitative methods (Tashakkori, Teddlie, 2003; Johnson, Onwuegbuzie, 2004; Creswell, Plano Clark, 2007; Molina-Azorin et al, 2012) and focuses on the result of a survey conducted on a sample of Italian social cooperatives. The presented study is an exploratory one: to the best of our knowledge, in Italy no datasets or surveys about gender composition in social enterprises (or, in general, in third sector) are available. For the selection of the panel, a purposeful sample of social cooperatives was chosen. The purposeful sample (Patton, 2002) is a kind of non-probability sampling technique - often characterized by a small number of units - used in qualitative research in order to focus on particular characteristics of a certain population choosing cases that are "information rich". The sample should also be consistent with the aims and the assumptions of the research, and it is generally preferred in pilot or exploratory analyses. The social cooperatives within the sample were chosen selecting the organizations with women as the majority of members and a woman in the role of president. This choice was made in order to minimize the influence of male presence in the SCs' governance so to exclusive underline female positions and situations. The selection was conducted online through an analysis of cooperatives' websites and direct contacts with the members of the chosen organizations in order to confirm the presence of the abovementioned characteristics. As shown in Table 1, eight Italian SCs were chosen (A-type, B-type, and A+B-type), created in the previous five years (to highlight the possible difficulties in the start-up phase), still operating today.

Table 1. Main information on the sample

\begin{tabular}{lllll}
\hline $\begin{array}{l}\text { Type of } \\
\text { cooperative }\end{array}$ & $\begin{array}{l}\text { Year of } \\
\text { foundation }\end{array}$ & Main activity & $\begin{array}{l}\text { Members } \\
\text { (female } \\
\text { members) }\end{array}$ & $\begin{array}{l}\text { Area of } \\
\text { activity }\end{array}$ \\
\hline B & 2015 & Retailing of organic foods and products & $12(11)$ & Local \\
\hline B & 2012 & $\begin{array}{l}\text { Management of historical and cultural areas and } \\
\text { touristic services }\end{array}$ & $4(4)$ & Local \\
\hline B & 2014 & Cultural services for disabled people & $5(3)$ & National \\
\hline B & 2011 & Art workshop & $3(2)$ & Local \\
\hline B & 2011 & Textile workshop, ecodesign & $6(5)$ & National \\
\hline A & 2010 & Personal care services & $11(11)$ & Local \\
\hline A & 2011 & Educational and social rehabilitation services & $6(5)$ & Local \\
\hline A+B & 2013 & $\begin{array}{l}\text { Services for parenting support, management of a } \\
\text { family center }\end{array}$ & $5(5)$ & Local \\
\hline & & & & \\
\hline
\end{tabular}

An online survey was prepared and, according to Fowler (2014), was pre-tested by two colleagues and by two women with similar characteristics of the possible respondents, in order to receive suggestions and feedbacks. Then, the social cooperatives were contacted in order to get the personal email address of the president to whom the survey was directly sent. The questions were organized in three different sections: "general information on the social cooperative"; "personal information about the president", and the last one entitled "social cooperative and gender gap", trying to underline, according to literature, the presence and the possible interconnections among individual factors (micro-level), structural conditions (macro-level), organizational processes (meso-level). 
For the first two parts, related to the objective information on the organizations (number of members, year of foundation, main activity, etc.) and to the personal information of the president (age, social status, education, previous work experience), open questions was structured, while, in the third section, multiple choice questions were preferred for most of the subjects. The multiple answers were prepared based on the literature review presented in the previous paragraphs and, even though they have the limit to "suggest" the answer, offer to the respondent a better understanding of the question itself, and make the findings easier to analyse and more significant. This weakness was also partially reduced by the possibility to choose more than one answer for every question and by the presence of the category "other" as a residual option, which makes it possible to add personal answers.

Table 2. Information on the president of the social cooperative

\begin{tabular}{llll}
\hline Age & Education & Type (years) of previous work experience & $\begin{array}{l}\text { Status (n. of } \\
\text { children) }\end{array}$ \\
\hline 52 & High school degree & Administrative employee (27) & Single (1) \\
\hline 57 & Master degree & Financial and insurance consultant (8) & Single (0) \\
\hline 60 & Medium school degree & Entrepreneur (25) & Married (3) \\
\hline 41 & High school degree & Employee (10) & Married (1) \\
\hline 45 & High school degree & Hotel reception manager (20) & Single (1) \\
\hline 46 & Master degree & Social worker (10) & Married (3) \\
\hline 40 & Master degree & Social worker (10) & Single (0) \\
\hline 38 & Master degree & Social worker (15) & Single (1) \\
\hline
\end{tabular}

Particularly, the focus of this latter part was on the further topics: personal motivations ("why did you decide to set up a social cooperative?"); institutional/family role ("what was the role of institutions in the creation of the organization?", "how did your family support your choice?"); cultural context ("is there a stereotypic vision of women in the entrepreneurial context? Why?"); opportunities/constraints ("what were the main obstacles to the constitution of the social cooperative?", "does the no-profit sector offer better job opportunities for women? Why?"). Finally, some questions were prepared about the female condition and the role of president, the relation with employees, and the business, in order to analyse organizational implications.

The findings of the survey are highlighted in the next paragraph; names and identities were anonymized for privacy reasons.

\section{Research Findings}

As the first step, the analysis focused on the motivations (individual factors) related to the creation of the social cooperative. All presidents involved in the survey collaborated with the other members in setting up the organization: to this sense, was interesting to deepen the way they arrived to the decision to create their social cooperative. In particular, eight possible answers were presented, but they could write additional reasons in the residual category "other". There also was the opportunity to choose more than one option. The structure of the question and the answers are presented in the table below (Figure 1). 


\section{Why did you decide to set up a social cooperative? (multiple answers can be selected)}

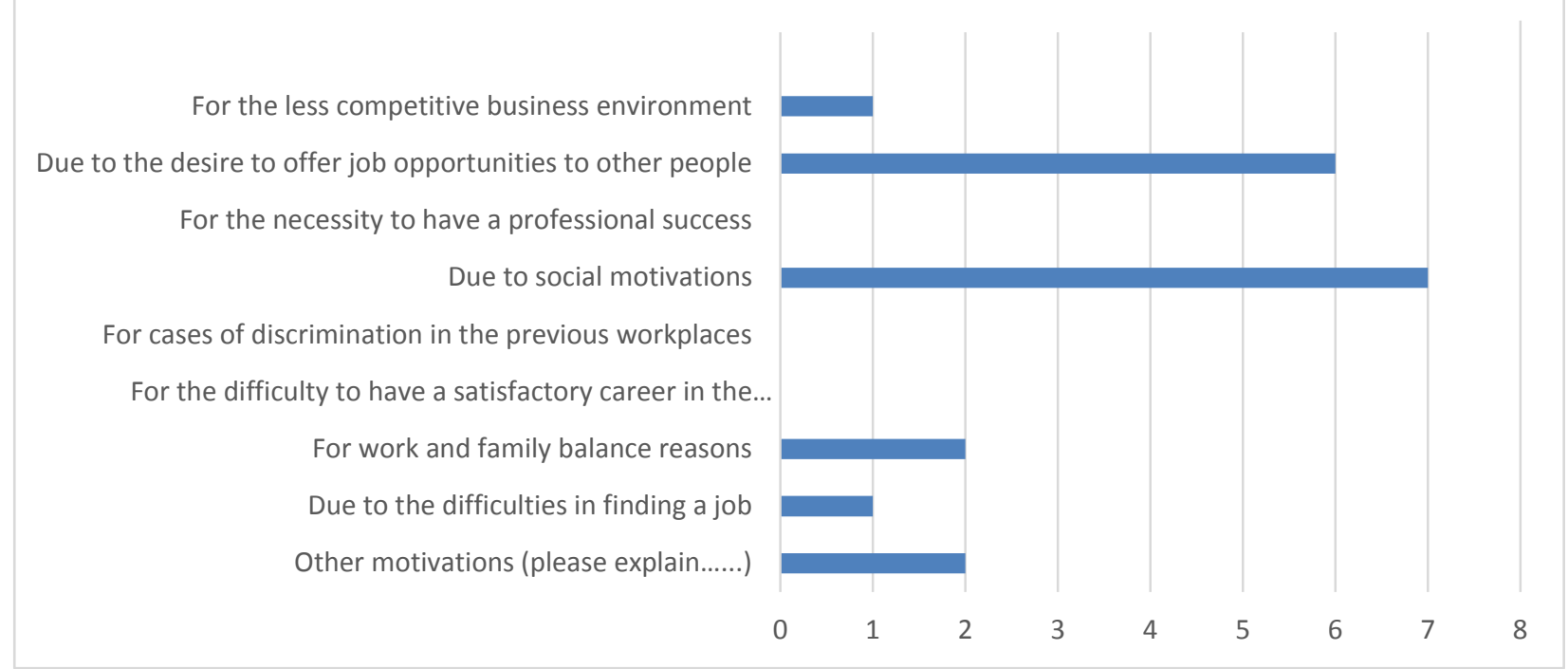

Figure 1. Personal motivations

Most of the chosen answers are related to "relational and altruistic matters": almost the entire group, indeed, declared to have decided to set up the organization due to social motivations and in order to offer job opportunities to other people. Remarkably, there is no connection with previous job experiences both in terms of career ("difficulty to have a satisfactory career in the previous job"), bad experiences ("cases of discrimination in the previous workplaces"), and professional success: no one, in fact, chose these options as motivations related to the cooperative foundation. Marginal are other reasons. Two respondents have also added personal motivations, related probably to their life experience: the first one wrote that a cause was her passion for the local territory and for the other one the presence of a disabled person as a family member. Surprisingly, this latter respondent did not choice, as another possible answer, the balance between work and family as a motivation for setting up a social initiative.

Concerning family and institutional support, cultural context, and main constraints (structural conditions), all the respondents declared the central role of the family in the developed of their activity, in terms of financial resources given directly for the foundation of the SC (5 out of 8), of collaboration for the household organization (3 out of 8), and of an active participation to the SC and its events (3 out of 8). Not all SCs received public grants and funds for the constitution (just 5 out of 8), while 2 respondents declared also the presence of the public patronage for their initiatives. Various are the financial supports given by the institutions and they could be both national and local: local recruitment incentives, regional cooperatives funds, national funds, and specific funds for female entrepreneurship initiatives.

The cultural context is viewed as an adverse element: almost all answers ( 7 out of 8 ) to the question "is there a stereotyped vision of women in the entrepreneurial context? Why?" are positive, and the subtended motivations are often related to the traditional vision of female roles. One woman, in fact, put it in these words:

"generally speaking, there is still a tendency to consider a woman just as a mother and a housewife", and another one: "every woman is still represented only as a mother, wife and lover [...], just think about the advertising campaigns or talk shows where female entrepreneurs are considered just a rarity to be shown".

The entrepreneurial and working attitudes are deemed as another source of discrimination: "there is a stereotyped vision because people tend to favour men in the working career", and again "women struggle a lot to be recognized as good entrepreneurs". It is noteworthy that the only woman who answered negatively, explaining the motivations of her answer, wrote:

"women are naturally different by men, this is not a stereotype but a fact [...], unfortunately it is necessary to become a man to enter in the labour market". 
Also, for the question about the main constraints, a multiple-choice structure was preferred, with the opportunity to choose more than one answer. The results are shown in Figure 2.

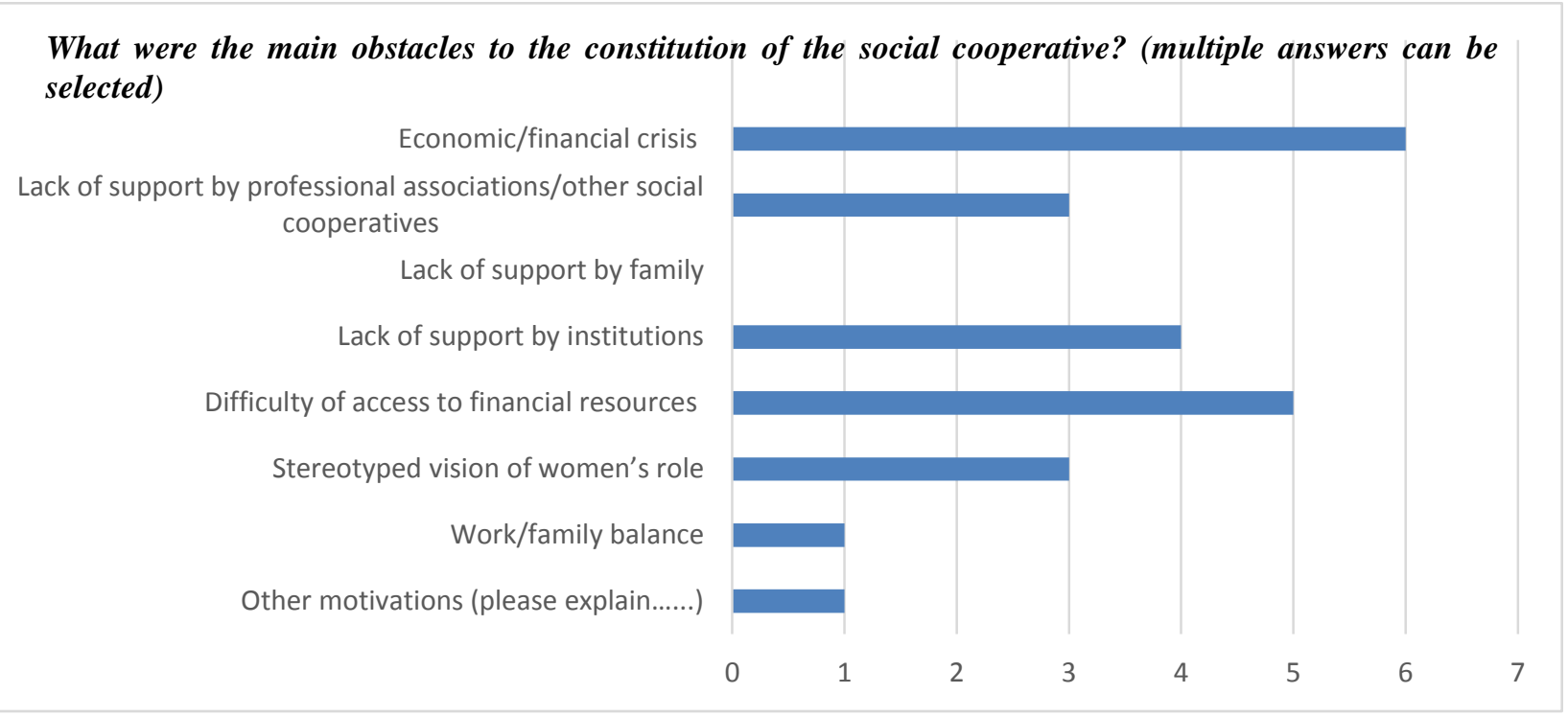

Figure 2. Main constraints

The obstacles concern the difficulty of access to financial resources and the economic crisis. These elements are in some cases viewed in relation with a lack of support by institutions and by professional associations and other SCs. Not surprisingly, it is not considered a constraint the family, but the necessity to find a balance between work and family-life, that for two respondents appears an opportunity (motivation for setting up an entrepreneurial initiative, as shown in Figure 1) in this case for one woman appears to be as a constraint. The stereotyped vision of women's role remains for someone a problem, as it can also be seen below. One respondent, using the open answer, argued that another difficulty is related to the high level of bureaucracy and taxes. Not all the respondents believe that no-profit sector could represent an opportunity for female entrepreneurship. Just 5 women answered positively to the question “does the no-profit sector offer better job opportunities for women? Why?". Particularly, according to some answers, the prerogative of the third sector is to emphasize female attitudes:

"no-profit sector gives to women the possibility to use creativity and imagination, typical female characteristics"

or

"we have more opportunities than in the traditional market-oriented sector also because the activity run by a A-type social cooperative is a traditional and typical female responsibility: the care-giving activity".

On the other hand, who did not recognize specific differences between profit and non-profit sector, argued "no-profit organizations have the same problems of traditional profit enterprises; the central topic is actually to support all business initiatives".

Finally, the last part of the questions was related to the possible influence between female condition of the president and her institutional role, the relation with employees, and the implication on the activity run by the SC (organizational processes). In relation of the institutional role of president, some respondents recognized a degree of influence with the fact of being woman. Particularly, two respondents declared a negative influence related to the stereotypical vision of female entrepreneur, and just one a positive influence concerning the presence of empathy, collaboration and multitasking skills. However, this connection is practically absent for the other two topics (employees and activity). In other words, all respondents did not tie their gender with a different relation with workers and/or the activity run by their SC. 
Despite these results, however, it has to be noted that almost in the entire sample (7 out of 8) flexible jobs forms are used (Table 3).

Table 3. Typology of flexible job form

\begin{tabular}{llll}
\hline & Part time contracts & Managing autonomously the working time & Work from home \\
\hline 1. & $\mathrm{X}$ & & $\mathrm{X}$ \\
\hline 2. & $\mathrm{X}$ & $\mathrm{X}$ & $\mathrm{X}$ \\
\hline 3. & & $\mathrm{X}$ & $\mathrm{X}$ \\
\hline 4. & $\mathrm{X}$ & & $\mathrm{X}$ \\
\hline 5. & & $\mathrm{X}$ & \\
\hline 6. & & $\mathrm{X}$ & \\
\hline 7. & $\mathrm{X}$ & $\mathrm{X}$ & \\
\hline 8. & & &
\end{tabular}

It is also to be noted that the only one respondent (n. 5) that does not declare flexible job contacts is a B-type cooperative in which the disadvantaged category is represented by female inmates, for whom these contracts are inapplicable.

\section{Discussion of Findings}

The findings presented in the previous section highlight interest points of discussion and contribute to clarify the role of personal and contextual factors in the development of women social entrepreneurial initiatives. Particularly, as for personal motivations and opportunity recognition, the results show the presence of relational and altruistic matters as primary reasons of SC's creation, whilst seems to be no connection with previous work experience, in terms of career, job discrimination or professional success. This is also confirmed by the fact that most of the respondents does not have previous job experience as social workers, that is to say any profession concerned with helping individuals, families, groups and communities to enhance their individual and collective well-being. The pre-eminence of social motivations behind SC's start-up seems to be consistent with previous studies that underlined female attitude to emphasize social and environmental value creation (Hechavarria et al, 2012; Nicolás, Rubio, 2016; Themudo, 2009) and female attitudes toward long term helping and altruistic behaviours (Eagly, Crowley, 1986; Eckel, Grossman, 1998; Huysentruyt 2014, Urbano Pulido et al, 2014), and volunteer activities (DiMaggio, Louch, 1997). Findings also suggest that social entrepreneurial attitude seems to not develop for all "during time" and in a "specific professional way" (most of the respondents do not have previous job experiences in no-profit sector), but seems to emerge in a certain point of their life (it is also to be noted that almost all women are over 40) after a long and different working career. Further studies could deepen this issue, trying to clarify if this situation is related just to a "gradual consciousness" about a personal contribution to social matters in terms of entrepreneurial activity or it concerns simply economic and structural constraints (that is to say, for example, lack of capitals or time).

Results show that women's family can support SC in different ways, even if the first one remains the financial support. Regarding this latter aspect, it is also confirmed the variety of funding used by SCs (with a overlaps of diverse financial resources), although most of the respondents claims for having more support by institutions (mostly local ones) and signals a difficult access to finance, as underlined also by recent EU survey (Policy Department Citizen's Rights and Constitutional Affairs, 2015). The presence of the family as financial supporter - as declared by some respondents - could underline also a sort of "indirect barrier": the possibility to set up an entrepreneurial initiative could be accessible just in the case of women with wealthy background. Actually, our information does not allow us to deepen this issue, but is surely a topic to be explored with future studies. Besides, it is worth noting that the necessity to balance work and family life is not a central motivation to start a social enterprise. As finding showed, just 2 respondents chose this option: they have children and they are among the youngest of the group, and neither is the respondent who claimed to have a disabled family member.

From a socio-cultural point of view, the findings confirm the persistence of a stereotyped vision of women, even if in a sector more "women-oriented". Almost all respondents highlighted an "entrepreneurial discrimination" that, starting from broader commonplaces on the role of women in society (mothers, lovers, housewives, and so on), influences deeply the vision of a woman as a good entrepreneur, even social entrepreneur. At this stage of analysis, it 
is not possible to verify specific influences of these stereotyped visions in business: this could represent an interesting point to be supplemented by further research.

Another possible point of interest is the result related to the relationship between the gender of SC's president and organizational matters. Substantially no one considers her condition having any influence on the activity run by organization, or with employees, whilst who has recognized a degree of influence with the institutional role, indicated a negative relation, probably related to the stereotypic vision of women. As for the relationship with employees, it is significant the presence of a lot of flexible job forms, and this confirms the broader diffusion, in the third sector, of family friendly benefits (Conry, McDonald, 1994; Lanfranchi, Narcy, 2015; Mirvis, 1992).

\section{Conclusive Remarks}

In recent times the interest on female entrepreneurship has involved also third sector, as highlighted by several studied focusing on the role of women in the development of social entrepreneurial initiative also in comparison with the characteristics of men entrepreneurs. Nonetheless this increasing interest about social businesswomen, to date few studies appear to be published (Teasdale et al, 2011; Gawell, Sundin, 2014). Moreover, current literature on women and social enterprise is mostly related to disparity in leadership positions, wage-gap and composition of workforce, especially in US and UK (Gibleman, 2000; Mesch, Rooney, 2008; Sampson, Moore, 2008, Teasdale et al, 2011). In light of this situation, this exploratory study had the aim to offer some insights for contributing to the analysis of the interconnection among context, personal perceptions and the developing of women's social enterprise through a country-specific analysis and focusing on a specific juridical form: the Italian social cooperative.

Results suggest the significance, also for social businesswomen, of social, institutional and cultural context (De Bruin et al, 2007), and of personal perceptions (Hechavarria et al, 2012; Nicolás, Rubio, 2016; Themudo, 2009). The respondents perceived that they still faced obstacles due to an adverse socio-cultural context and a lack of institutional support, probably offset by the support of family and their personal involvement.

As a preliminary analysis on the theme and due to the presence of few cases, the research admittedly has a number of limitations. The evidence gathered is also based on self-reporting, hence raising the possibility of a potential response bias. Nonetheless these limitations, this study could offer interesting suggestions and could represent an interesting starting point for further analysis on women's role and engagement in social entrepreneurial initiative.

\section{References}

Ahl, H. (2006). Why Research on Women Entrepreneurs Needs New Directions. Entrepreneurship Theory \& Practice, 30(5), 595-621.

Borzaga, C., \& Santuari, A. (2001). Italy: From Traditional Co-operatives to Innovative Social Enterprises. In C. Borzaga, \& J. Defourny (Eds.), The emergence of Social Enterprise. Routledge, New York.

Bowden, B. (2016). Editorial and Note on the Writing of Management History. Journal of Management History, 22(2), 118-129.

Bruni, A., Gherardi, S., \& Poggio, B. (2004). Entrepreneur-mentality, Gender and the Study of Women Entrepreneurs. Journal of Organizational Change Management, 17(3), 256-268.

Brush, C. G., \& Cooper, S. Y. (2012). Female Entrepreneurship and Economic Development: An International Perspective. Entrepreneurship \& Regional Development, 24(1-2), 1-6.

Brush, C. G., de Bruin, A., \& Welter, F. (2009). A Gender-Aware Framework for Women's Entrepreneurship. International Journal of Gender and Entrepreneurship, 1(1), 8-24.

Brush, C., Carter, N., Gatewood, E., Greene, P., \& Hart, M. (Eds.) (2006). Growth-Oriented Women Entrepreneurs and Their Businesses: A Global Research Perspective. Edward Elgar, Cheltenham.

Bruton, G. D., Ahlstrom, D., \& Li, H. (2010). Institutional Theory and Entrepreneurship: Where Are We Now and Where Do We Need to Move in the Future?. Entrepreneurship Theory and Practice, 34(3), 421-440.

Carter, N. M., Brush, C. G., Greene, P., Gatewood, E., \& Hart, M. H. (2003). Women Entrepreneurs Who Break Through to Equity Financing: The Influence of Human, Social and Financial Capital. Venture Capital, 5(1), 1-28.

Conry, J. C., \& McDonald, J. E. (1994). Moving Toward a Matrix: Gender and the Nonprofit Culture of the Nineties. Philanthropic Fundraising, 5, 45-53. 
Creswell, J., \& Plano Clark, V. (2007). Designing and Conducting Mixed Methods Research. Thousand Oaks, CA: Sage.

Datta, P. B., \& Gailey, R. (2012). Empowering Women through Social Entrepreneurship: Case Study of a Women's Cooperative in India. Entrepreneurship Theory and Practice, 36(3), 569-587.

Davidsson, P., \& Wiklund, J. (2001). Levels of Analysis in Entrepreneurship Research: Current Research Practice and Suggestions for the Future. Entrepreneurship Theory \& Practice, 31(3), 365-386.

De Bruin, A., Brush, C., \& Welter, F. (2007). Advancing Framework for Coherent Research on Women's Entrepreneurship. Entrepreneurship Theory \& Practice, 31(3), 323-339.

Defourny, J., \& Nyssens, M. (2008). Social Enterprise in Europe: Recent Trends and Developments. Social Enterprise Journal, 4(3), 202-228.

DiMaggio, P. J., \& Powell, W. (Eds.) (1991). The New Institutionalism and Organizational Analysis. Chicago, University of Chicago Press.

DiMaggio, P., \& Louch, H. (1997). Who Volunteers? Dominant and Relevant Statuses. Washington, DC, Aspen Institute, Nonprofit Sector Research Fund.

Doe, H. (2017). Gender and Business. Women in Business or Businesswomen? An Assessment of the History of Entrepreneurial Women. In J. F. Wilson, S. Toms, A. de Jong, \& E. Buchnea (Eds.), The Routledge Companion to Business History (pp. 347-357). Routledge, New York.

Du Rietz, A., \& Henrekson, M. (2000). Testing the Female Underperformance Hypothesis. Small Business Economics, 14(1), 1-10.

Eagly, A. H., \& Crowley, M. (1986). Gender and Helping Behavior: A Meta-analytic Review of the Social Psychological Literature. Psychological Bulletin, 100(3), 283-308.

Eckel, C., \& Grossman, P. (1998). Are Women Less Selfish Than Men? Evidence from Dictator Experiments. Economic Journal, 108(448), 726-735.

Elam, A., \& Terjesen, S. (2010). Gendered Institutions and Cross-National Patterns of Business Creation for Men and Women. European Journal of Development Research, 22(3), 331-348.

EU Directorate-General for Internal Policies. (2015). Women's entrepreneurship: closing the gender gap in access to financial and other services and in social entrepreneurship. Retrieved January, 24, 2017, from http://www.europarl.europa.eu/studies

Fasci, M., \& Valdez, J. (1998). A Performance Contrast of Male- and Female-Owned Small Accounting Practices. Journal of Small Business Management, 36(3), 1-7.

Faulk, L., Edwards, L. H., Lewis, G. B., \& McGinnis, J. (2013). An Analysis of Gender Pay Disparity in the Nonprofit Sector: An Outcome of Labor Motivation or Gendered Jobs?. Nonprofit and Voluntary Sector Quarterly, 43(6), 1268-1287.

Fischer, E. M., Reuber R. A., \& Dyke L. S. (1993). A Theoretical Overview and Extension of Research on Sex, Gender, and Entrepreneurship. Journal of Business Venturing, 8(2), 151-168.

Fossen, F. M. (2012). Gender Differences in Entrepreneurial Choice and Risk Aversion. A Decomposition based on a Microeconometric model. Applied Economics, 44(14), 1795-1812.

Fowler, F. J. (2014). Survey Research Method (5th ed.). Sage, University of Massachusetts, Boston.

Gamber, W. (1998). A Gendered Enterprise: Placing Nineteenth-Century Businesswomen in History. The Business History Review, 72(2), 188-217.

Gawell, M., \& Sundin, E. (2014). Social Entrepreneurship, Gendered Entrepreneurship?. In Lundström, A., Zhou, C., von Friedrichs, Y., \& Sundin, E. (Eds.), Social Entrepreneurship. Leveraging Economic, Political, and Cultural Dimensions (pp. 273-291). Springer.

GEDI. (2015). Female Entrepreneurship index 2015.

Gibelmann, M. (2000). The Nonprofit Sector and Gender Discrimination. Non Profit Management and Leadership, $10(3), 251-269$.

Gras, D., Mosakowski, E., \& Lumpkin, G. T. (2011). Gaining Insights from Future Research Topics in Social Entrepreneurship: A Content-Analytic Approach. In G. T. Lumpkin, \& J. A. Katz (Eds.), Social and Sustainable 
Entrepreneurship. Advances in Entrepreneurship, Firm Emergence and Growth. Emerald Group Publishing Limited.

Haugh, H. (2005). A Research Agenda for Social Enterprise. Social Enterprise Journal, 1(1), 1-12.

Hechavarria, D. M., Ingram, A., Justo, R., \& Terjesen, S. (2012). Are Women more likely to Pursue Social and Environmental Entrepreneurship?. In K. D. Hughes, \& J. E. Jennings (Eds.), Global Women's Entrepreneurship Research: Diverse Settings, Questions, and Approaches. Edward Elgar Publishing, Northampton.

Hughes, K. D., Jennings, J. E., Brush, C., Carter, S., \& Welter, F. (2012). Extending Women's Entrepreneurship Research in New Directions. Entrepreneurship Theory \& Practice, 36(3), 429-442.

Humbert, A. L. (2012). Women as social entrepreneurs. Third Sector Research Centre, Birmingham, Working Paper, 72.

Huysentruyt, M. (2014). Women's Social Entrepreneurship and Innovation. OECD Local Economic and Employment, Development (LEED) Working Papers.

Jamali, D. (2009). Constraint and Opportunities Facing Women Entrepreneurs in Developing Countries. A Relational Perspective. Gender in Management: An International Journal, 24(4), 232-251.

Jennings, J. E., \& Brush, C. G. (2013). Research on Women Entrepreneurs: Challenges to (and from) the Broader Entrepreneurship Literature?. The Academy of Management Annals, 7(1), 663-715.

Johnson, B., \& Onwuegbuzie, A. (2004). Mixed Methods Research: A Research Paradigm whose Time has Come. Educational Researcher, 33(7), 4-26.

Klyver, K., Nielsen, S. L., \& Evald, M. R. (2013). Women's Self-employment: An Act of Institutional (dis)integration? A Multilevel, Cross-country Study. Journal of Business Venturing 28(4), 474-488.

Lanfranchi, J., \& Narcy, M. (2015). Female Overrepresentation in Public and Nonprofit Sector Jobs. Nonprofit and Voluntary Sector Quarterly, 44(1), 47-74.

Leete, L. (2000). Wage Equity and Employee Motivation in Nonprofit and For-profit Organizations. Journal of Economic Behavior \& Organization, 43(4), 423-446.

Levie, J., \& Hart, M. (2011). Business and Social Entrepreneurs in the UK: Gender, Context and Commitment. International Journal of Gender and Entrepreneurship, 3(3), 200-217.

Light, P. (2008). The Search for Social Entrepreneurship. Washington DC: Brookings Institution.

Luchsinger, G. (2015). UN woman 2014-2015 annual report. New York.

Mancino, A., \& Thomas, A. (2005). An Italian Pattern of Social Enterprise: The Social Cooperative. Nonprofit Management and Leadership, 15, 357-369.

Manolova, T. S., Brush, C. G., Edelman, L. F., \& Shaver, K. G. (2012). One Size does not Fit All: Entrepreneurial Expectancies and Growth Intentions of US Women and Men Nascent Entrepreneurs. Entrepreneurship \& Regional Development, 24(1-2), 7-27.

Marlow, S. (2014). Exploring Future Research Agendas in the Field of Gender and Entrepreneurship. International Journal of Gender and Entrepreneurship, 6(2), 102-120.

McGinnis, J. (2011). The Young and Restless: Generation Y in the Nonprofit Workforce. Public Administration Quarterly, 35(3), 342-362.

Mesch, D. J., \& Rooney, P. M. (2008). Determinants of Compensation: A Study of Pay, Performance, and Gender Differences for Fundraising Professionals. Nonprofit Management and Leadership, 18(4), 435-463.

Meyer, J., \& Rowan, B. (1991). Institutionalized Organizations: Formal Structure as Myth and Ceremony. In W. Powell, \& P. DiMaggio (Eds.), The New Institutionalism in Organizational Analysis. Chicago, University of Chicago Press.

Miles, M. B., \& Huberman, A. M. (1994). Qualitative data analysis: An expanded sourcebook (2nd ed.). Sage, Thousand Oaks.

Minniti, M., \& Schade, C. (2011). Gender Differences in Entrepreneurial Propensity. Oxford Bulletin of Economics \& Statistics, 75(2), 1-39. 
Minniti, M., Arenius, P., \& Langowitz, N. (2005). 2004 Global Entrepreneurship Monitor Special Topic Report: Women and Entrepreneurship. Babson Park, Massachusetts.

Molina-Azorin, J. F., López-Gamero, M. D., Pereira-Moliner, J., \& Pertusa-Ortega, E. (2012). Mixed Methods Studies in Entrepreneurship Research: Applications and Contributions. Entrepreneurship \& Regional Development, 24(5-6), 425-456.

Nicolás, C., \& Rubio, A. (2016). Social Enterprise: Gender Gap and Economic Development. European Journal of Management and Business Economics, 25(2), 56-62.

North, D. C. (1990). Institution, Institutional Change and Economic Performance. Cambridge University Press, Cambridge.

Patton, M. Q. (2002). Qualitative Research and Evaluation Methods (3rd ed.). Sage Publications, Thousand Oaks.

Preston, A. (1990). Changing Labor Market Patterns in the Nonprofit and For-Profit Sectors. Nonprofit Management and Leadership, 1(1), 15-28.

Preston, A. E. (1989). The Nonprofit Worker in a For-profit World. Journal of Labour Economics, 7, 438-463.

Preston, A., \& Sacks, D. W. (2010). Nonprofit Wages: Theory and Evidence. In D. R. Young, \& B. Seaman (Eds.), Handbook of Research on Nonprofit Economics and Management. Edward Elgar Publishing.

Robb, A. (2002). Entrepreneurial Performance by Women and Minorities: the Case of New Firms. Journal of Developmental Entrepreneurship, 7(4), 383-397.

Robb, A. M., \& Watson, J. (2012). Gender Differences in Firm Performance: Evidence from New Ventures in the United States. Journal of Business Venturing, 27(5), 544-558.

Rosa, P., Carter, S., \& Hamilton, D. (1996). Gender as a Determinant of Small Business Performance: Insights from a British Study. Small Business Economics, 8(6), 463-478.

Salamon, L. M., \& Sokolowski, S. W. (2006). Employment in America's Charities: A Profile. NED Bulletin, 26.

Sampson, S. D., \& Moore, L. L. (2008). Is There a Glass Ceiling for Women in Development?. Nonprofit Management and Leadership, 18(3), 321-339.

Scott, W. R. (2008). Approaching Adulthood: The Maturing of Institutional Theory. Theory and Society, 37(5), 427-442.

Shaw, E., \& Carter, S. (2007). Social Entrepreneurship: Theoretical Antecedents and Empirical Analyses of Entrepreneurial Processes and Outcomes. Journal of Small Business and Enterprise Development, 14(3), 418-434.

Tashakkori, A., \& Teddlie, C. (Eds.) (2003). Handbook of Mixed Methods in Social \& Behavioral Research. Thousand Oaks, CA: Sage.

Teasdale, S, McKay, S., Phillimore, J., \& Teasdale, N. (2011). Exploring Gender and Social Entrepreneurship: Women's Leadership, Employment and Participation in the Third Sector and Social Enterprises. Voluntary Sector Review, 2(1), 57-76.

Teasdale, S. (2010). What's in a Name? The Construction of Social Enterprise. Working paper 46, Birmingham: TSRC.

Themudo, N. S. (2009). Gender and Non Profit Sector. Non Profit and Voluntary Sector Quarterly, 38(4), 663-683.

Thomas, A. (2004). The Rise of Social Cooperative in Italy. Voluntas: International Journal of Voluntary and Non profit Organizations, 15(3), 243-263.

Urbano Pulido, D., Ferri Jiménez, E., \& Noguerai Noguera, M. (2014). Female Social Entrepreneurship and Socio-cultural Context: an International Analysis. Revista de Estudios Empresariales. Segunda época, 2, 26-40.

Watson, J. (2002). Comparing the Performance of Male- and Female-Controlled Businesses: Relating Outputs to Inputs. Entrepreneurship Theory \& Practice, 26(3), 91-100.

Watson, J. (2003). Failure Rates for Female-Controlled Businesses: Are They any Different?. Journal of Small Business Management, 41(3), 262-277.

Watson, J., \& Robinson, S. (2003). Adjusting for Risk in Comparing the Performance of Male- and Female-Controlled SMEs. Journal of Business Venturing, 18(6), 773-788. 
Welsh, D. H., Kaciak, E., \& Thongpapanl, N. (2016). Influence of Stages of Economic Development on Women Entrepreneurs' Startups. Journal of Business Research, 69(11), 4933-4940.

Welter, F. (2010). Entrepreneurship. Conceptual Challenges and Ways Forward. Entrepreneurship Theory \& Practice, 35(1), 165-184.

Welter, F. (2011). Contextualising Entrepreneurship: Conceptual Challenges and Ways Forward. Entrepreneurship Theory \& Practice, 35(1), 165-184.

WeStart. (2015). Mapping Women's Social Entrepreneurship in Europe. European Women's Lobby. 